\title{
Correction to: Genetic diversity and evolutionary history of Korean isolates of severe fever with thrombocytopenia syndrome virus from 2013-2016
}

\author{
Mi-ran Yun ${ }^{1}$ D $\cdot$ Jungsang Ryou ${ }^{2} \cdot$ Wooyoung Choi $^{3} \cdot$ Joo-Yeon Lee $^{2} \cdot$ Sun-Whan Park ${ }^{4}$ (D) Dae-Won Kim ${ }^{1}$
}

Published online: 11 September 2020

(c) The Author(s) 2020

\section{Correction to: Archives of Virology https://doi.org/10.1007/s00705-020-04733-0}

Authors would like to correct the 4th author name from "JuYeon Lee" to the correct version "Joo-Yeon Lee".

The original article has been corrected.

Open Access This article is licensed under a Creative Commons Attribution 4.0 International License, which permits use, sharing, adaptation, distribution and reproduction in any medium or format, as long as you give appropriate credit to the original author(s) and the source, provide a link to the Creative Commons licence, and indicate if changes were made. The images or other third party material in this article are included in the article's Creative Commons licence, unless indicated otherwise in a credit line to the material. If material is not included in

The original article can be found online at https://doi.org/10.1007/ s00705-020-04733-0.

Sun-Whan Park

sunwhan@korea.kr

$\triangle$ Dae-Won Kim

todaewon@gmail.com

1 Pathogen Resource TF, Center for Infectious Diseases

Research, Korea National Institute of Health, Korea

Centers for Disease Control and Prevention, 200

Osongsaengmyeong2-ro, Heungdeok-gu, Cheogju-si,

Chungbuk 28160, Republic of Korea

2 Division of Emerging Infectious Disease and Vector Research, Center for Infectious Diseases Research, Korea National Institute of Health, Korea Centers for Disease Control and Prevention, 187 Osongsaengmyeong2-ro, Heungdeok-gu, Cheogju-si, Chungbuk 28160, Republic of Korea

3 Division of Viral Diseases, Center for Laboratory control of Infectious Disease, Korea Centers for Disease Control and Prevention, 187 Osongsaengmyeong2-ro, Heungdeok-gu, Cheogju-si, Chungbuk 28160, Republic of Korea

4 Jeju National Quarantine Station, Korea Centers for Disease Control and Prevention, 356 Central Goverment office-Jeju, 59 Cheongsa-ro, Jeju-si 63219, Republic of Korea the article's Creative Commons licence and your intended use is not permitted by statutory regulation or exceeds the permitted use, you will need to obtain permission directly from the copyright holder. To view a copy of this licence, visit http://creativecommons.org/licenses/by/4.0/.

Publisher's Note Springer Nature remains neutral with regard to jurisdictional claims in published maps and institutional affiliations. 